\title{
EUDONTOMYZON DANFORDI (REGAN, 1911) SPECIES POPULATIONS ECOLOGICAL STATUS IN MARAMURES MOUNTAINS NATURE PARK (ROMANIA)
}



* "Lucian Blaga" University of Sibiu, Faculty of Sciences, Dr. Ion Raţiu Street 5-7, Sibiu, Sibiu County, Romania, RO-550012, angela.banaduc@ulbsibiu.ro

** "Lucian Blaga" University of Sibiu, Faculty of Sciences, Dr. Ion Raţiu Street 5-7, Sibiu, Sibiu County, Romania, RO-550012, oanadanci@gmail.com

*** "Lucian Blaga” University of Sibiu, Applied Ecology Research Center, Dr. Ion Raţiu Street 5-7, Sibiu, Sibiu County, Romania, RO-550012, ad.banaduc@yahoo.com

KEYWORDS: Carpathian lamprey, habitats, human impact, assessment.

DOI: 10.1515/trser-2015-0071

\section{ABSTRACT}

The Eudontomyzon danfordi characteristic habitats state of Maramureş Mountains Nature Park varies greatly, $19.05 \%$ are in excellent conservation status, $47.62 \%$ are in good/average status and $33.33 \%$ are in a partially degraded condition.

The identified human impact categories which induced the decreasing of Eudontomyzon danfordi species habitat state in the studied area are: poaching, minor riverbeds morphodynamic changings, liquid and solid natural flow disruption, destruction of riparian trees and bush vegetation, habitat fragmentation-fish populations isolation, and organic/mining pollution activities.

RESUMEN: Estado ecológico de las poblaciones de Eudontomyzon danfordi (Regan, 1911) en el Parque Natural Montañas Maramureș (Rumania).

El estado de las características del hábitat de Eudontomyzon danfordi en el Parque Natural Montañas Maramureş varió significativamente, 19.05\% están en excelente estado de conservación, $47.62 \%$ están en un estado de preservación bueno/regular y el 33.33\% están en condiciones parcialmente degradadas.

En este estudio, las categorías identificadas de impacto humano que indujeron deterioro del hábitat de Eudontomyzon danfordi son: caza ilegal o furtiva, cambios morfodinámicos de pequeños cauces, modificación del flujo natural de líquidos y sólidos, destrucción de la vegetación riparia, fragmentación del hábitat de poblaciones de peces, actividades orgánicas contaminantes y minería.

REZUMAT: Starea ecologică a populațiilor de Eudontomyzon danfordi (Regan, 1911) în Parcul Natural Munţii Maramureşului (România).

Starea habitatelor caracteristice speciei Eudontomyzon danfordi din Parcul Natural Munţii Maramureşului variază mult, 19,05\% sunt într-o stare de conservare excelentă, 47,62\% într-o stare bună/medie şi 33,33\% într-o stare redusă/degradată.

Categoriile de impact uman care induc scăderea stării de favorabilitate a habitatelor speciei Eudontomyzon danfordi în aria studiată sunt: braconajul, modificarea morfodinamicii naturale a albiilor minore, dereglările debitelor naturale lichide şi solide, distrugerea vegetaţiei ripariene arboricole şi arbustive, fragmentarea habitatelor - izolarea populaţiilor de peşti, poluarea organică şi poluarea cauzată de activităţile miniere. 


\section{INTRODUCTION}

The lotic ecosystems of the Maramureș Mountains Nature Park are in majority part of the Vișeu River catchment and some of the Bistrița Aurie catchment (Fig. 1), in northern Romania. The Vișeu Basin is bordered by the Maramureș Mountains in the northeast, by Rodna Mountains in the south, and by the Maramureș hills in the west and southwest. The lowest point of the basin is $303 \mathrm{~m}$ above sea level at the confluence of the Vișeu and Tisa rivers, while the highest point reaches 2,303 m altitude, the Pietrosul Rodnei Peak in Rodna Mountains. Due to its geological, tectonic and geographical complexity (glacial, karst, exokarst relief forms, etc.), the catchment area is largely diverse in landscapes, implicitly having a large variety of biotopes, biocoenosis, including ichtyocoenosis. (Curtean-Bănăduc et al., 2008; Bănăduc et al., 2011)

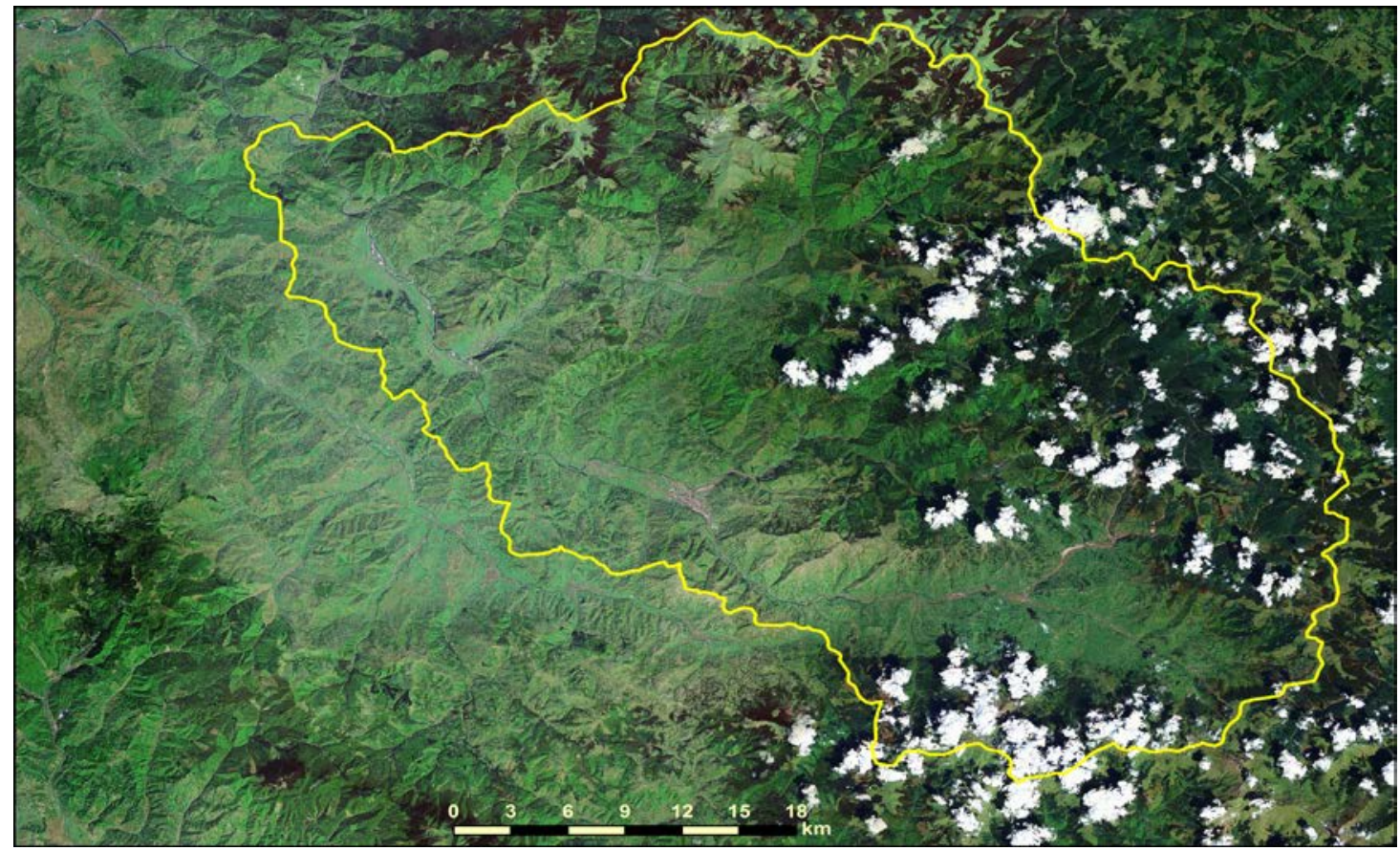

Figure 1: Vișeu River basin.

The Vişeu River is a second degree tributary of the Danube, flowing into the Tisa River. It has $80 \mathrm{~km}$ in length and a multiannual average flow $30.7 \mathrm{~m}^{3} / \mathrm{sec}$. at its confluence with the Tisa River. The origin is located in Prislop Pass $(1,416 \mathrm{~m})$ and it flows into Tisa near Valea Vișeului Village, the catchment area covering $1,606 \mathrm{~km}^{2}$. In its upper part, from springs to the town of Moisei, the Vișeu River has a large slope $(20-50 \mathrm{~m} / \mathrm{km})$ and is locally named Borşa or Vișeuț. From Moisei, the Vișeu enters the Maramureș Depression where the valley is wider, although some narrow gorge-like passages subsist: Rădeasa Gorges between Moisei and Vișeu de Sus, Oblaz Gorges between Vișeu de Jos and Leordina, and Vișeu Gorges between Bistra and Valea Vișeului. The hydrography of Vișeu River is of Eastern-CarpathianMoldavian type in its upper part and of Eastern-Carpathian-Transylvanian type in its lower half. Its discharge is substantial in the springtime (39.4\% of the annual discharge) subsequently decreasing during the summer (27\% of the annual discharge) as well as during the autumn (18.6\% of the annual discharge) and reaching its lowest during wintertime (15\% of the annual discharge). (Curtean-Bănăduc et al., 2008; Bănăduc et al., 2011) 
The fact that the Vișeu Catchment area is situated mainly in mountainous areas (67\%) leads to a high density of the hydrographic network $\left(0.7-1 \mathrm{~km} / \mathrm{km}^{2}\right)$ and to one of the largest specific discharges in Romania, due to rain and snowfall of more than 1,100 mm/year. In the upper part, the tributaries originating in the glacial-type Rodna Mountains, have an elevated discharge (approximatively five $\mathrm{m}^{3} / \mathrm{sec}$.). The most important Rodna-originating tributaries of Vişeu are: Fântânilor Valley (seven km length), Negoiasa Valley (six km), Repedea Valley (10 km), Pietroasa Valley (seven km), Vremeșu Valley, Hotarului Stream, Dragoș's Valley $(11 \mathrm{~km})$ and Izvorul Negru (seven km). From the Maramureș Mountains, the right side tributaries are: Hășmașul Mic, Cercănel $(11 \mathrm{~km})$, Țâsșla $(20 \mathrm{~km})$, Vaser $(52 \mathrm{~km}$ in length and catchment area of $422 \mathrm{~km}^{2}$, with an average flow of nine $\mathrm{m}^{3} / \mathrm{sec}$. contributing by $27 \%$ to the total flow of Vișeu), Novăț (16 km, $88 \mathrm{~km}^{2}$ tributary of the Vaser), Ruscova (39 km in length and $435 \mathrm{~km}^{2}$ catchment area, average discharge of $11.3 \mathrm{~m}^{3} / \mathrm{sec}$.), Socolău (13 km in length and $72 \mathrm{~km}^{2}$ catchment area, tributary of the Ruscova), Repedea (19 km in length and $87 \mathrm{~km}^{2}$ catchment area, tributary of the Ruscova), Bardi (11 km in length and $32 \mathrm{~km}^{2}$ catchment area, tributary of the Ruscova), Covașnița (11 km in length and $34 \mathrm{~km}^{2}$ catchment area, tributary of the Ruscova), Frumușeaua (14 km in length) and Bistra (nine $\mathrm{km}$ in length). From the Maramureș hills originate the left-side tributaries with small water input: Drăguiasa, Cocicoi, Spinului, Plăiuț, Neagră and Luhei. (Curtean-Bănăduc et al., 2008; Bănăduc et al., 2011)

In the Vişeu River basin, water quality is locally influenced in a natural way by mineral springs (150 in Maramureş Mountains, about six in Rodnei Mountains and around five in Maramureş hills) with a relatively varied composition (bicarbonate, ferrous, sulphurous and saline) (Curtean-Bănăduc et al., 2008).

In the Rodnei and Maramureş mountain areas the lotic ecosystems continuity is sometimes interrupted by sizeable waterfalls and series of rapids, we mention the biggest of these waterfalls from the Rodnei Mountains: Cailor, Cimpoioasa Valley, Repedea Valley and Izvorul Verde, and from Maramureş Mountains we mention: Criva, Tomnatic and Bardău. Besides lotic ecosystems, there are also lentic ecosystems. Glacial lakes from Rodnei Mountains are located at an altitude over 1,900-1,950 m and were formed behind some deposits: Iezer Lake, Gropi Lake, Buhăiescu Lake, Rebra Lake, Negoiescu Lake and Cimpoieş Lake. As wetlands there are also eutrophic and oligotrophic marshes: Strungi Marsh, Tăul Obcioarei, Tăul Ihoasa, Jneapănul Hânchii, Pietrosul Barcăului Marsh, Tăul Băiţii, Preluca Meşghii, Vârtopul Mare Marsh, Tăul cu Muşchi and Bedreasca. The lakes from Maramureş Mountains are Lutoasa, Bârsănescu, Budescul Mare, Măgurii and Vinderel. On the Vişeu River couloir near Petrova locality, there is an area of ponds. (Curtean-Bănăduc et al., 2008; Bănăduc et al., 2011)

The diversity of aquatic and semi-aquatic habitats and their associated rare, endangered and endemic species from Vişeu Basin is complex, high and valuable under conservative aspect. The fish species are no exception in this area, as reported by different researchers relatively continuous over more than a century of ichthyologic studies in the area of interest (Bănărescu, 1964; Staicu et al., 1998; Curtean-Bănăduc et al., 2008). A half of the fish species are of conservative interest.

\section{MATERIAL AND METHODS}

The study for Eudontomyzon danfordi species populations mapping and conservation status assessment and the identified causes of the present situation, in the Maramureşului Mountains Nature Park was realised between January and July 2015, based on 370 sampling stations (Fig. 2, Tab. 2). 


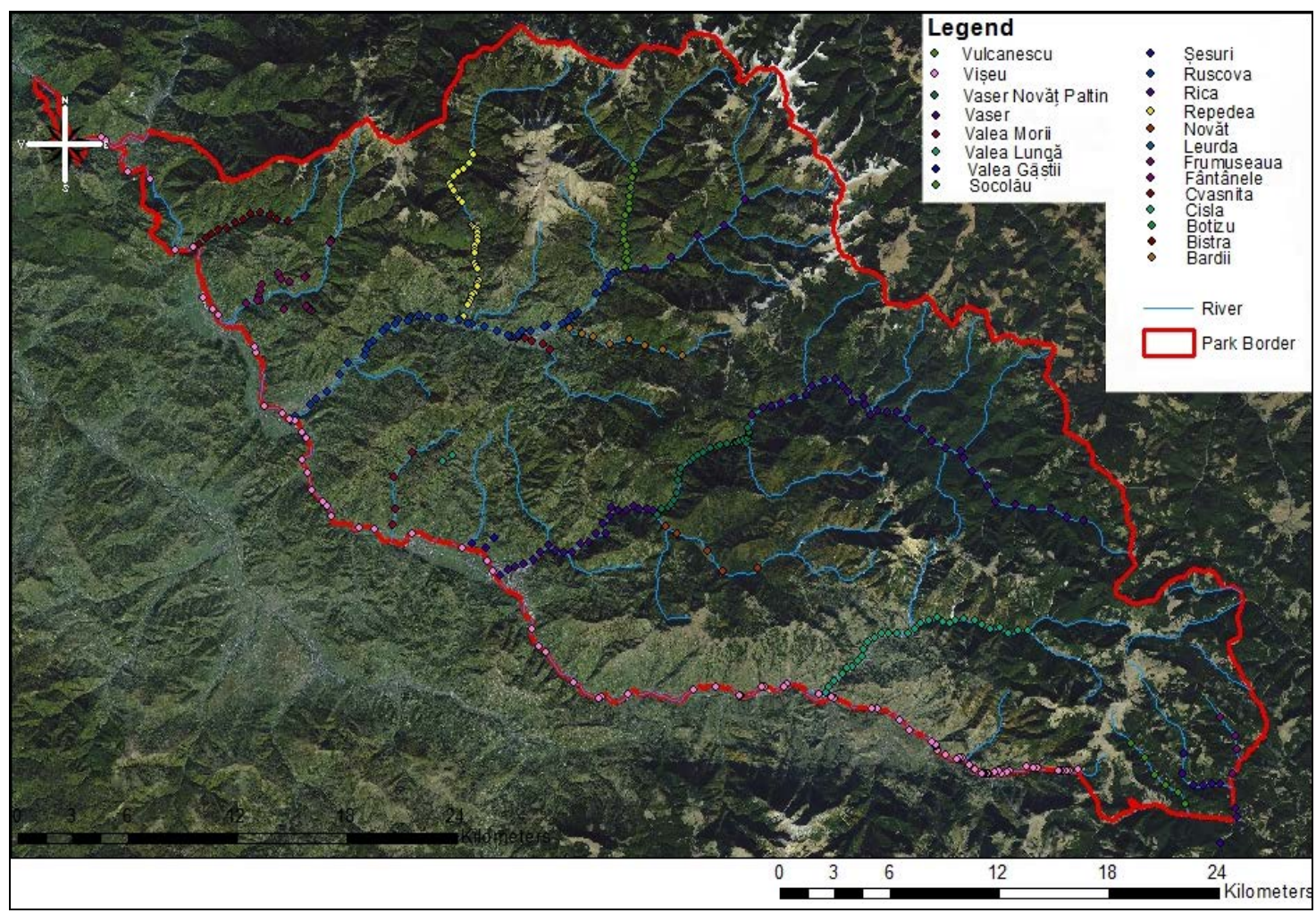

Figure 2: The 370 sampling stations location.

To assess the distribution and status of the fish species populations of conservative interest, quantitative samples were collected from around three to three kilometres between two consecutive stations along all watercourses included in the reference area, in areas with suitable habitats for the species of interest. This distribution of the sampling sectors ensures the representativeness of the collected data and allows the assessment of the effects on the target populations of the biotope condition changes, presence of pollution sources, of hydrotechnical works, substratum exploitation, poachers, etc.

Ichthyofauna quantitative sample collection was performed by the reversible electro narcosis capture method, per unit of time and effort per section (two hours on Vişeu River, one hour on Ruscova River, 30 minutes on the other rivers of the references zone), on five longitudinal sections of $100 \mathrm{~m}$ length. After species identification and counting individuals, the captured individuals were released in their habitat.

The number of individuals caught in the unity of time and effort can be transformed through correspondence in the classes: $(C)$ - common species, $(R)$ - rare species, or (V) - very rare, according to the guidelines for Natura 2000 standard data form filling, "In mammals, amphibians, reptiles and fishes, no numeric information can be indicative and then the size/density of the population is evaluated as (C) - common species, (R) - rare species, or (V) - very rare species”.

The criteria used to assess the population status are: population size, balanced distribution of individuals by age classes, distribution areal size and the percentage of individuals of the species of interest in the structure of fish communities. 
According to Natura 2000 guidelines, standard data form filling the criteria "The conservation degree of specific habitats" includes subcriteria: i) the degree of conservation of the habitat features which are important for the species; ii) possibilities for recovery.

The criteria i) requires a global evaluation of the features of the habitat regarding the needs of the species of interest. "The best expertise" is used to rank this criterion in the following way: I. elements in excellent condition, II. well preserved elements, III. elements in average or partially degraded condition.

In the cases in which the subclass I is granted "I: elements in excellent condition" or "II: well preserved elements," the criteria B (b) should be classified entirely as "A: excellent conservation" or "B: good conservation", regardless of the other sub-criterion classification.

In the case of this sub-criterion ii) which is taken into account only if the items are averagely or partially degraded, an evaluation of the viability of the analysed population is necessary. The obtained ranking system is: I. easy recovery; II. restoration possible with average effort; III. restoration difficult or impossible.

The synthesis applied for classification is based on two sub-criteria: A-excellent conservation $=$ elements in excellent condition, regardless of classification of recovery possibility; B-good conservation = well preserved elements, regardless of classification of recovery possibility; B-good conservation = elements in average or partially degraded condition and easy to restore; C-average or reduced conservation $=$ all other combinations .

In every sampled sector, the following were assessed: condition, pressures/threats of habitats and populations of interested fish species.

The monitoring stations for fish population conservation status of the above mentioned species in the survey reference area were established not only in the river sectors in which these species populations are stable, presenting a favourable conservational status, well preserved characteristic habitats, but also in the river sectors situated at the limit of the distribution area in this site for the investigated species, sectors under human pressure that can jeopardize the populations status - the Representativity Criteria.

The economical criterion was also considered for establishing the monitoring stations, thus a medium number was set to supply the necessary information for the management decision process in order to be able to preserve a favourable status for the interest species population in the reference area.

Eudontomyzon danfordi Regan, 1911, Code Natura 2000: 4123, Cyclostomata Petromyzoniformes - Petromyzonidae (Fig. 4), was present in the studied area in the last century (Bănărescu, 1969; Telcean and Bănărescu, 2002; Bănăduc et al., 2013; Homei, 1963).

This fish species body is relatively compressed laterally in the anterior part with a height of 5.0 to $7.7 \%$ of the total length. The two dorsal fins have a space, which represents 2.3 to $6.8 \%$ of the body length between them. The first dorsal fin is round and not so high, while the second one is higher. Adults are dark grey and the ventral side is yellowish-whitish.

The larvae and adults feed on invertebrates. They live in mud, especially mixed with sand. The depth of which they are buried varies from 10 to $40 \mathrm{~cm}$. They are night hunters.

This species lives in rivers with mountain characters, in the trout, grayling and Mediterranean barbell zone, and is less frequently present in the nase upper area. The frequency of individuals of this species in various rivers and even in different parts of the same river is uneven, probably depending on the presence and abundance of sectors with slow water and silt in which the larvae are developing and the food is abundant. (Bănăduc, 2007a, b, 2008a, b, 2011; Bănăduc et al., 2012; Bănărescu, 1964, 1969; Bănărescu and Bănăduc, 2007). 


\section{RESULTS}

The lotic sectors where the species Eudontomyzon danfordi (Fig. 3) was identified during the study are presented in table 2 (Fig. 4), for each sector the catch index values were specified (individuals number per time and effort unit).

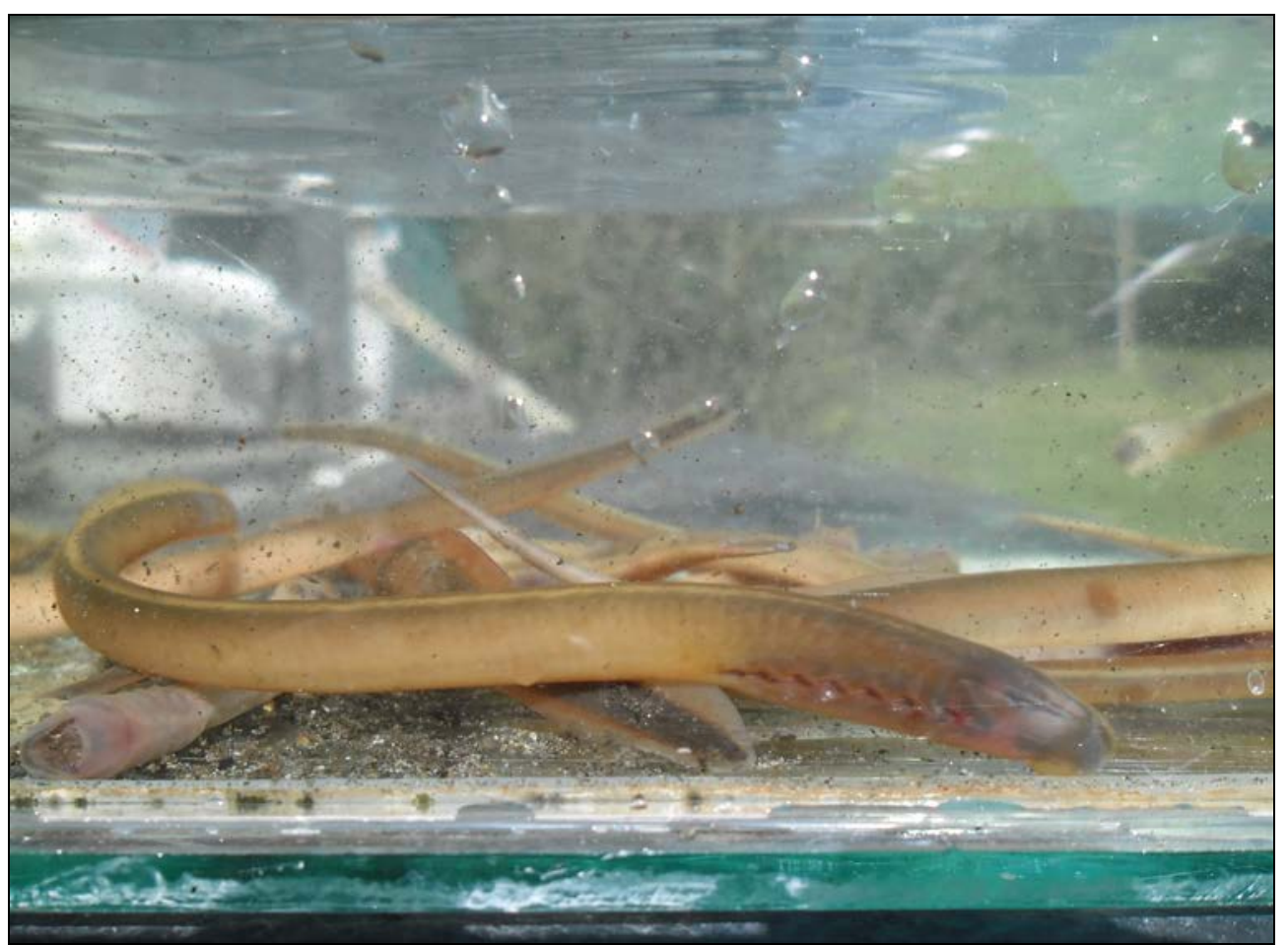

Figure 3: Eudontomyzon danfordi Regan, 1911.

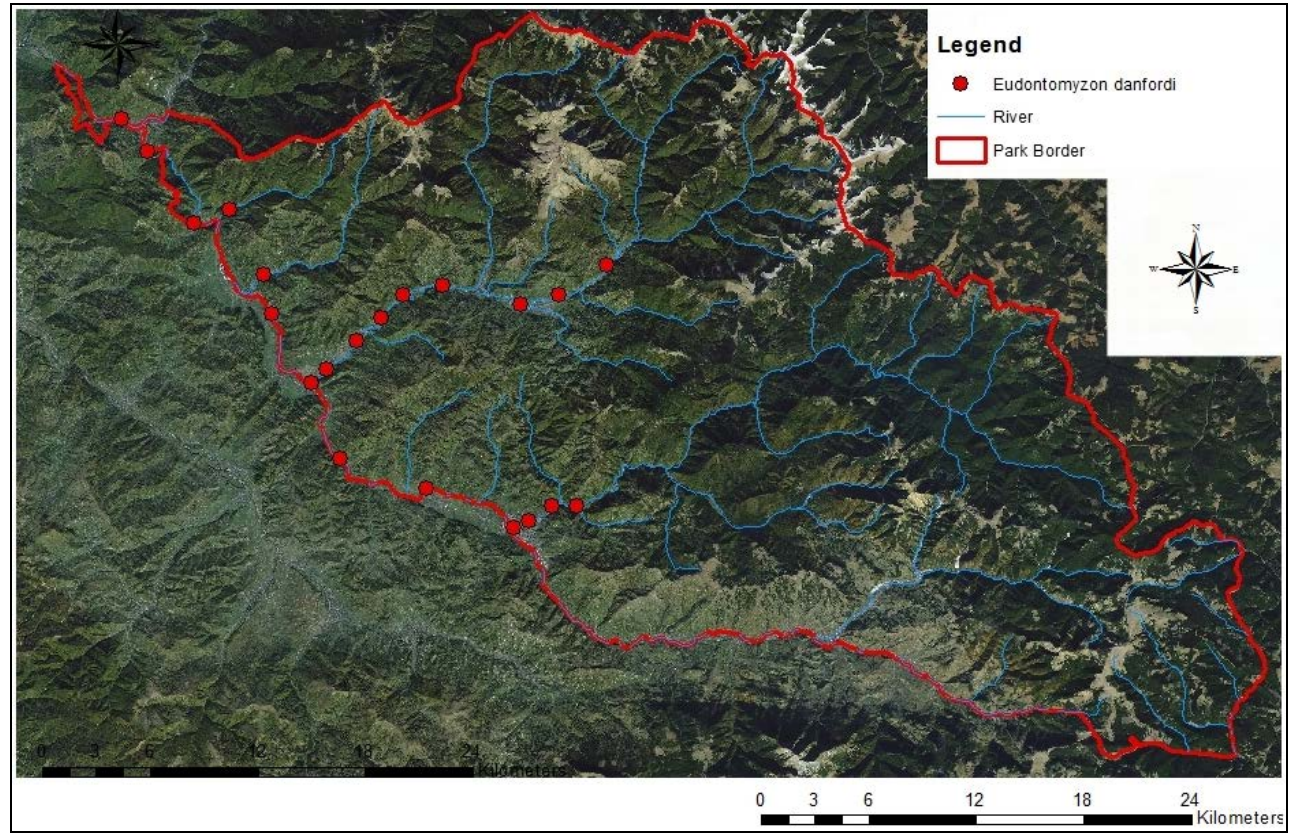

Figure 4: Eudontomyzon danfordi Regan, 1911 distribution/sampling stations location. 
Table 2: Eudontomyzon danfordi sampling points in Maramureș Mountains Nature Park.

\begin{tabular}{|c|c|c|c|c|c|c|}
\hline $\begin{array}{l}\text { No. } \\
\text { crt. }\end{array}$ & River & $\begin{array}{l}\text { Stati } \\
\text { on } \\
\text { code } \\
\end{array}$ & Lat. (N’) & Long. (E’) & $\begin{array}{l}\text { Catch index } \\
\text { no. ind./50 m } \\
\text { x } 30 \mathrm{~min} \\
\end{array}$ & $\begin{array}{c}\text { Characteristic } \\
\text { habitat state }\end{array}$ \\
\hline 1. & Vișeu & 54 & 474348.9 & 242142.8 & 1 & good/average \\
\hline 2. & Vişeu & 59 & 474442.4 & 241750.5 & 1 & good/average \\
\hline 3. & Vișeu & 65 & 474658.8 & 241632.2 & 2 & good/average \\
\hline 4. & Vișeu & 70 & 474903.6 & 241445.05 & 4 & good/average \\
\hline 5. & Vişeu & 75 & 475148.5 & 241112.4 & 10 & excellent \\
\hline 6. & Vișeu & 77 & 475400.9 & 240907.36 & 7 & excellent \\
\hline 7. & Vișeu & 79 & 475458.5 & 240755.7 & 6 & good/average \\
\hline 8. & Ruscova & 5 & 475039.7 & 242941.7 & 1 & reduced \\
\hline 9. & Ruscova & 11 & 474944.9 & 242734.2 & 1 & reduced \\
\hline 10. & Ruscova & 18 & 474925.8 & 242549.8 & 1 & reduced \\
\hline 11. & Ruscova & 26 & 474959.8 & 242219.9 & 2 & reduced \\
\hline 12. & Ruscova & 33 & 474941.7 & 242034.1 & 1 & reduced \\
\hline 13. & Ruscova & 37 & 474859.9 & 241938.6 & 3 & good/average \\
\hline 14. & Ruscova & 40 & 474817.8 & 241829.9 & 5 & good/average \\
\hline 15. & Ruscova & 43 & 474725.7 & 241712.1 & 1 & reduced \\
\hline 16. & Vaser & 46 & 474318.5 & 242822.7 & 1 & excellent \\
\hline 17. & Vaser & 49 & 474319.3 & 242718.3 & 1 & excellent \\
\hline 18. & Vaser & 52 & 474252.6 & 242615.3 & 2 & good/average \\
\hline 19. & Vaser & 54 & 474238.7 & 242534.6 & 5 & good/average \\
\hline 20. & Frumușeaua & 18 & 475016.8 & 241422.1 & 7 & good/average \\
\hline 21. & Bistra & 10 & 475215.7 & 241248.2 & 2 & reduced \\
\hline
\end{tabular}

Eudontomyzon danfordi individuals constitute in the studied area permanent populations on an average total surface of five hectares; the adequate surface of the habitat in this protected area is around 10 hectares (in the following basins: Vișeu - lower sectors, Ruscova - middle and lower, Vaser - lower, Frumușeaua - lower and Bistra - lower). The habitat surface of the species is big enough and the present tendency and quality of the habitat is adequate for the long term species survival.

The human impact, respectively the identified pressures in the studied area, have a medium cumulative effect, partially affecting the long-term viability of the species, with the condition that no new type of human impact will be involved and the existing ones will not increase in the future. 


\section{DISCUSSION}

Based on the results obtained from field activities, correlated with Eudontomyzon danfordi species biological and ecological needs, the following risk elements were identified (pressures and threats): poaching, minor riverbed morphodynamic changes, liquid and solid natural flow disruption, destruction of riparian vegetation, habitats fragmentation/fish populations fragmentation.

Poaching. During the field campaigns poaching activities were noticed with electric energy from car accumulators and equipment involved in forestry activities and from other types of rechargeable batteries. In other cases, poachers were seen during illegal activities using various substances (natural and synthetic) for killing fish and harvesting them downstream. By interviewing various people encountered in Maramureș Mountains Nature Park, it seems that poaching is a relatively frequent activity in all seasons through the Vișeu River basin. The inefficiency of controlling this phenomenon may lead to the number reduction of Eudontomyzon danfordi individuals and populations.

We propose increasing the number of field work hours for rangers in order to stop poaching in the protected area. The lack of financial resources that these activities involve for rangers can be partially offset through collaborative arrangements with forestry, police and gendarmerie personal, and last but certainly not least with the Romanian National Agency for Fishing and Aquaculture agents which should become the main player in this respect for controlling poaching at a national level, as well as a creation of volunteer structures.

Minor riverbed morphodynamic changings. Specific different habitat and microhabitat needs for this fish species, according to its life cycle stages, induce requirements for a natural variability of riverbed morphodynamics. Dikes, sills, dams, roads in riverbeds, changed riverbeds, riverbed mineral exploitation (Fig. 5), changed dynamics of liquids and solids flow, etc., all have a primary effect of modifying the natural morphodynamics of major and minor riverbeds and secondarily affected ones, if not all habitats and/or microhabitats predeterminant for the life cycle stages of the Eudontomyzon danfordi individuals, which could result in decreasing numbers of this species' populations.

Apparently harmless, a number of facilities on watercourses of interest (dikes, too high sills, dams, microhydropowerplants, water extractions, modifications in the riverbeds, riverbed mineral overexploitations, etc.) should not be allowed by Maramureș Mountains Nature Park Scientific Council and Administration without a proper/specific technical expertise for this species of conservation interest.

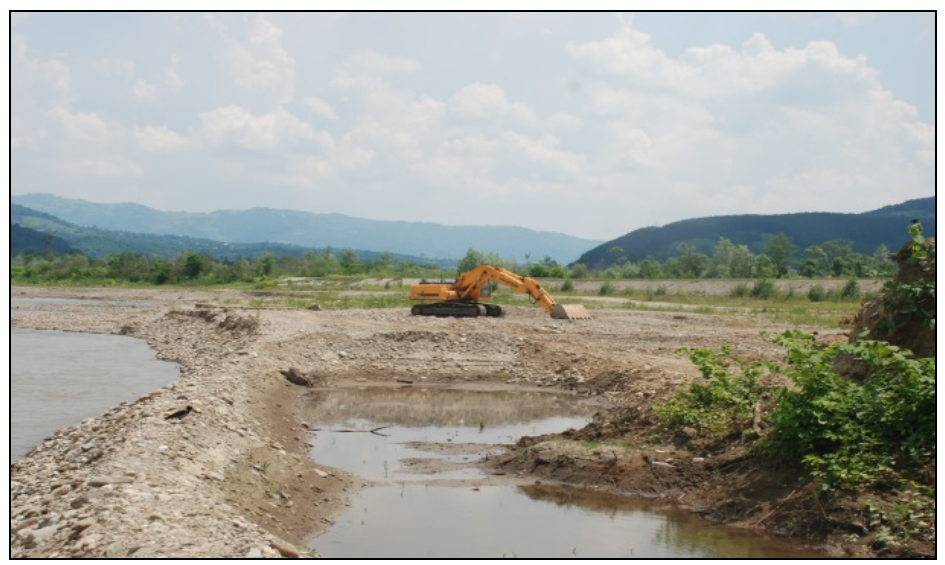

Figure 5: Minerals’ overexploitation in the lower Vișeu River riverbed, banks and terraces. 
Liquid and solid natural flow disruption. The liquid and solid natural flow disruption that created the conditions for formation and persistency of habitats and microhabitats adequate for the occurrence and development of the Eudontomyzon danfordi species population, may lead, in the context of modification of the natural morpho-dynamics of the riverbed, to the declining number of individuals of the species. The accidental episodes of artificial increase of water turbidity, due to negligent forestry in the proximity or in the very riverbed, are an example of the cause for disrupting the equilibrium of the liquid and solid natural flow.

The liquid and solid natural flow can be maintained as close as possible to the natural state if the forestry practices and/or riverbed grabble exploitations will not affect the capacity of the watershed to have a self-sustainable condition of practice, which can be achieved by correlating the human activities with the seasons and the periods when the natural conditions are similar to those to be created (high turbidity). Apparently harmless, a series of existing (Fig. 6) or possible works on the rivers of interest, such as embankments, crossings, dams, water extractions, bank modifications (Fig. 7), thalweg alterations by exploitations of construction materials from the riverbed, etc., are not allowed by the administrator of the site without the consent of specialists studying the species, based on the corroboration of the specific/local stress factor and the biological and ecological needs of the species of interest. In this particular case, for instance, no crossing should be higher than 10-15 $\mathrm{cm}$ in the shallow and dry season. We also suggest the monitoring of the forestry regulation surveillance including the interdiction of dragging and storage lumber through/in creeks and rivers. We also recommend the surveillance of the development works for lumber storage and exploitation platforms, (Fig. 8) and the mandatory requirement to reforestation. In this context, the rotation of exploitations in the sub-basins of the Vișeu River is preferable.

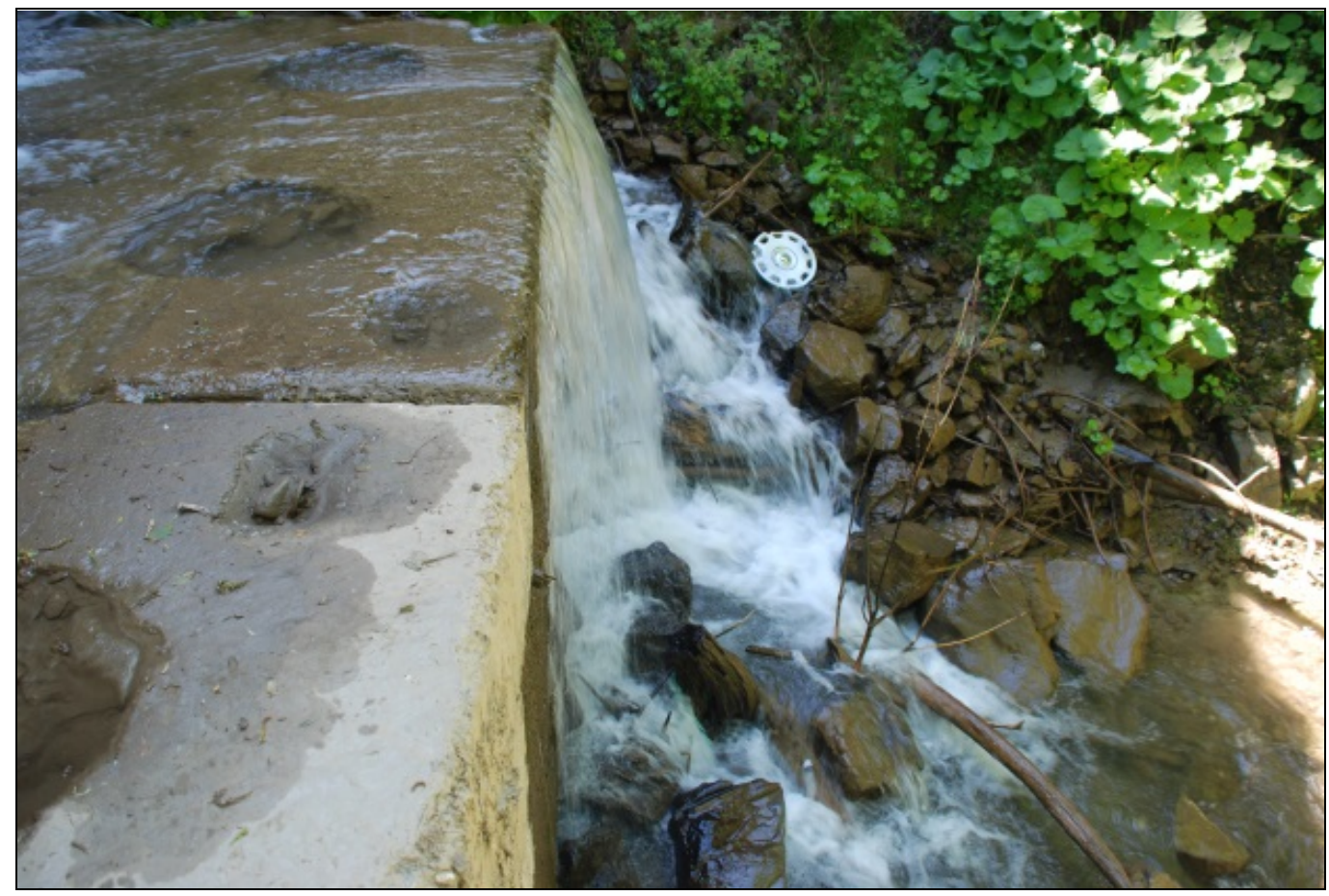

Figure 6: Concrete threshold of three $m$ height, with no fish ladder on the upper Vişeu River. 


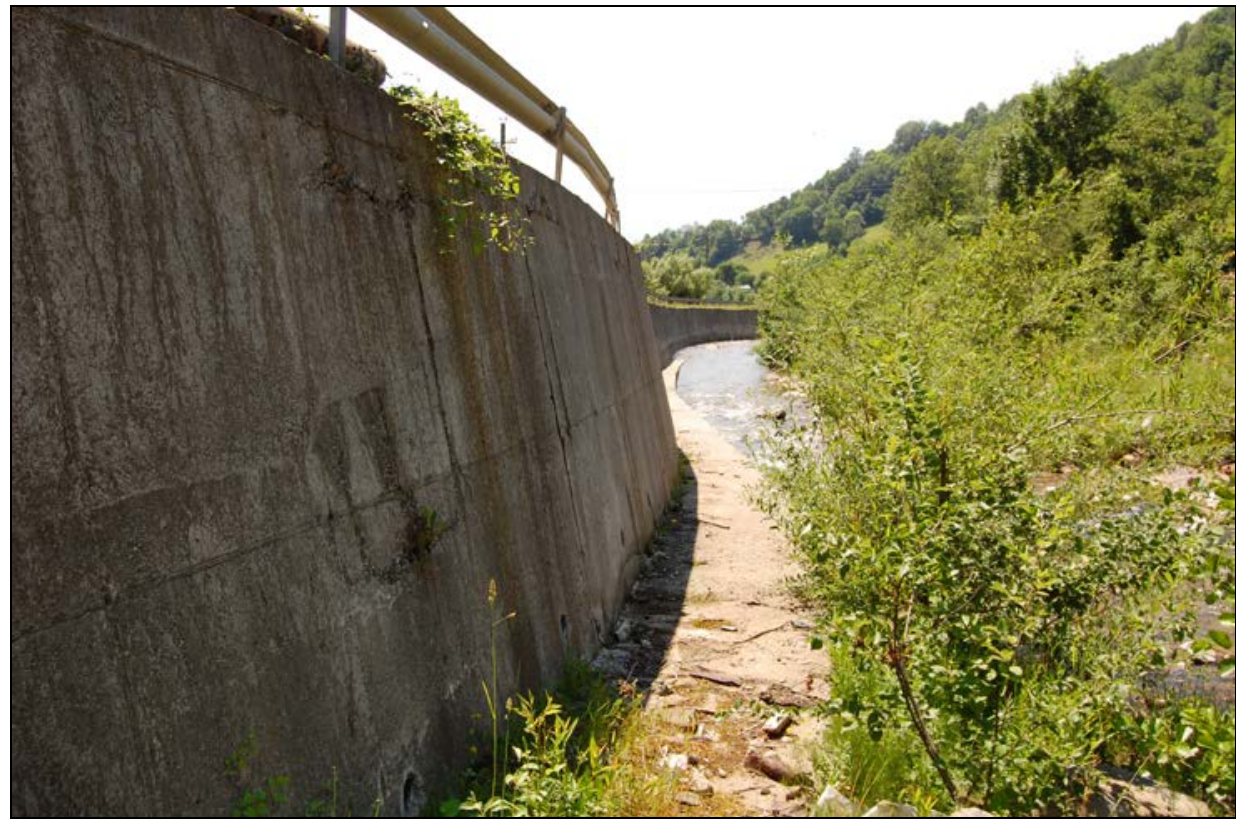

Figure 7: Frumuşeaua River concrete riverbank/completely modified.

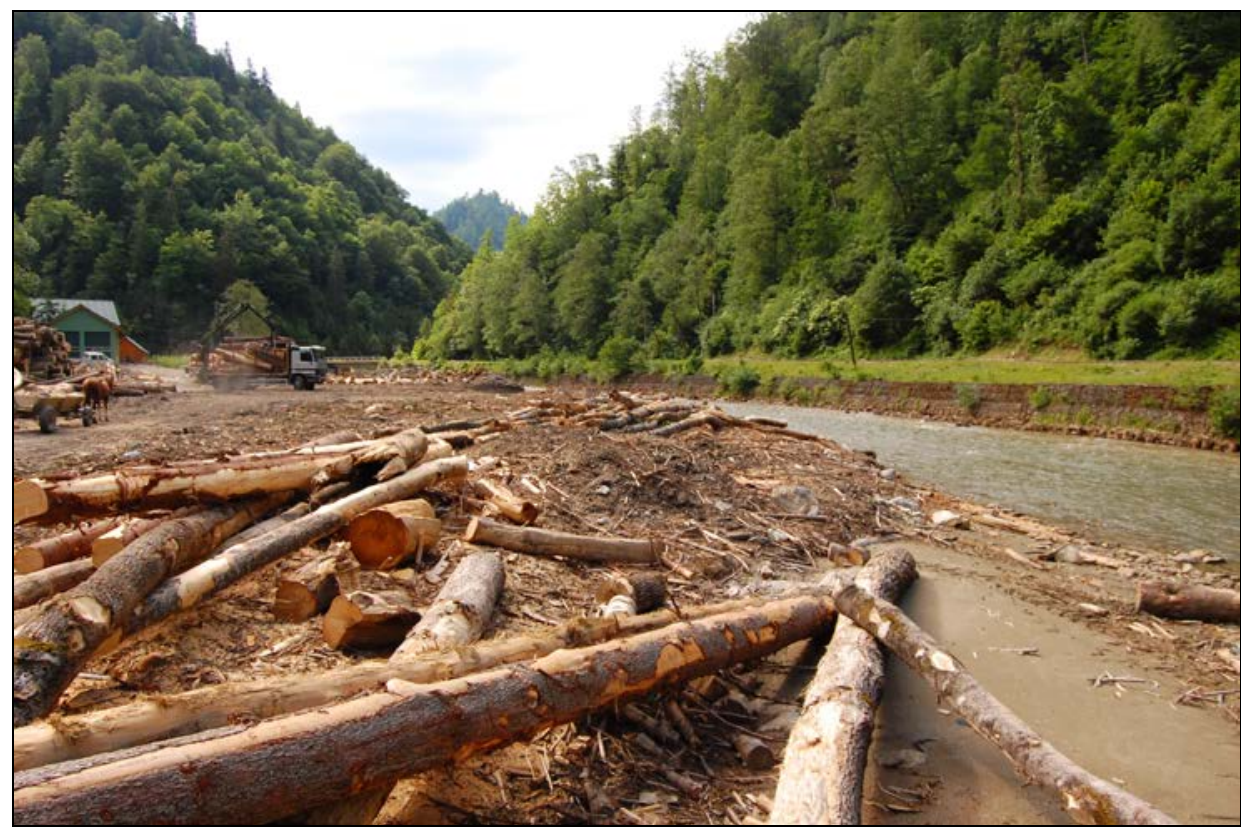

Figure 8: Logs transport and deposit on the Vaser River banks and in the riverbed.

Destruction of riparian trees and bush vegetation. Diminishing the riverine vegetation (Fig. 9), by partial/total destruction, both in the context of lessening the microclimate protection and that of trophic resources (Curtean-Bănăduc et al., 2014), can lead to a numerical reduction of ichthyofauna including the Eudontomyzon danfordi individuals populations. The arboreal and shrubs riparian vegetation must be as intact as possible on a minimum of 5-10 m width in the upper part of the rivers and of 10-25 $\mathrm{m}$ in their lower part. 


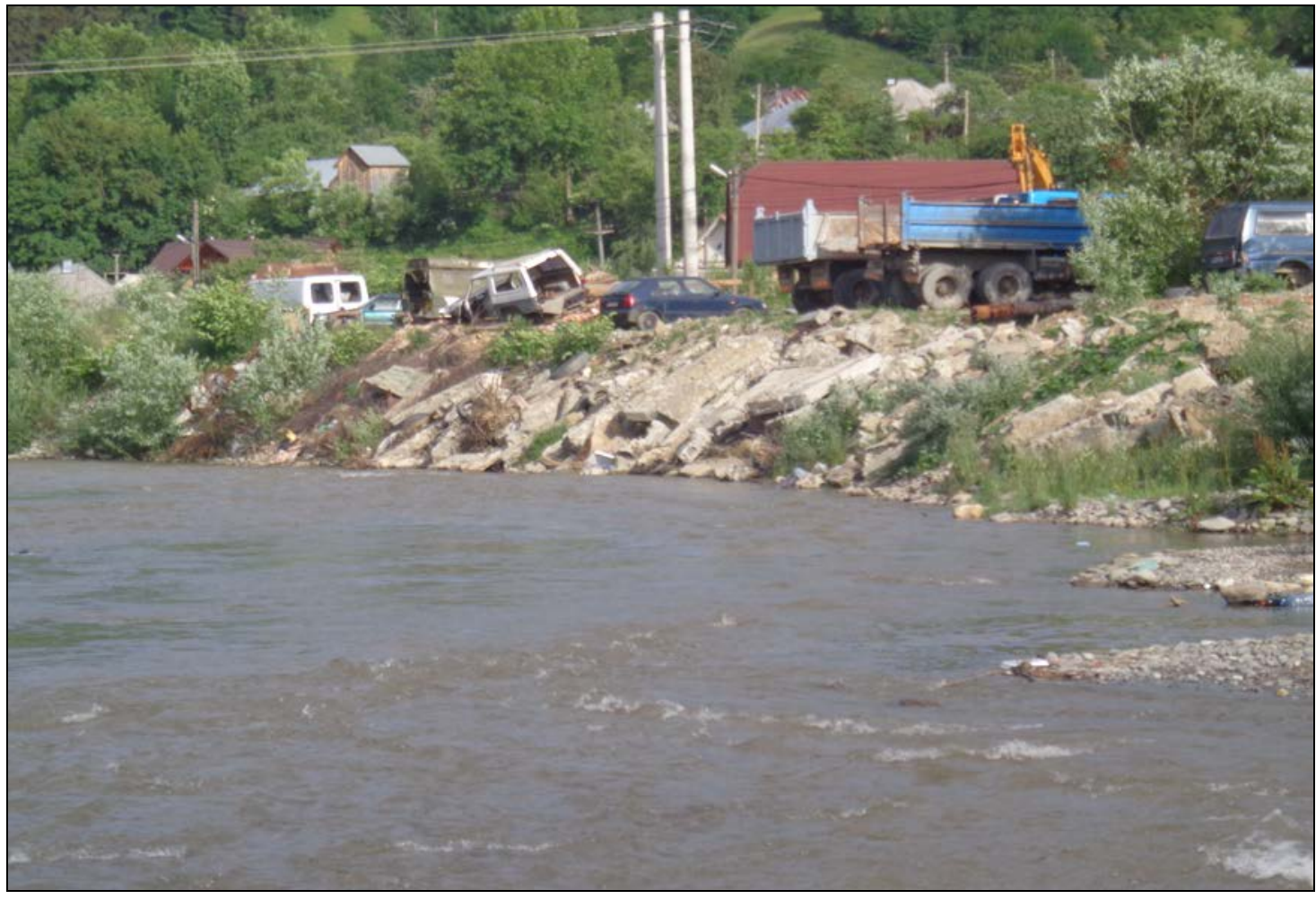

Figure 9: Destructed riparian vegetation on the Ruscova River banks.

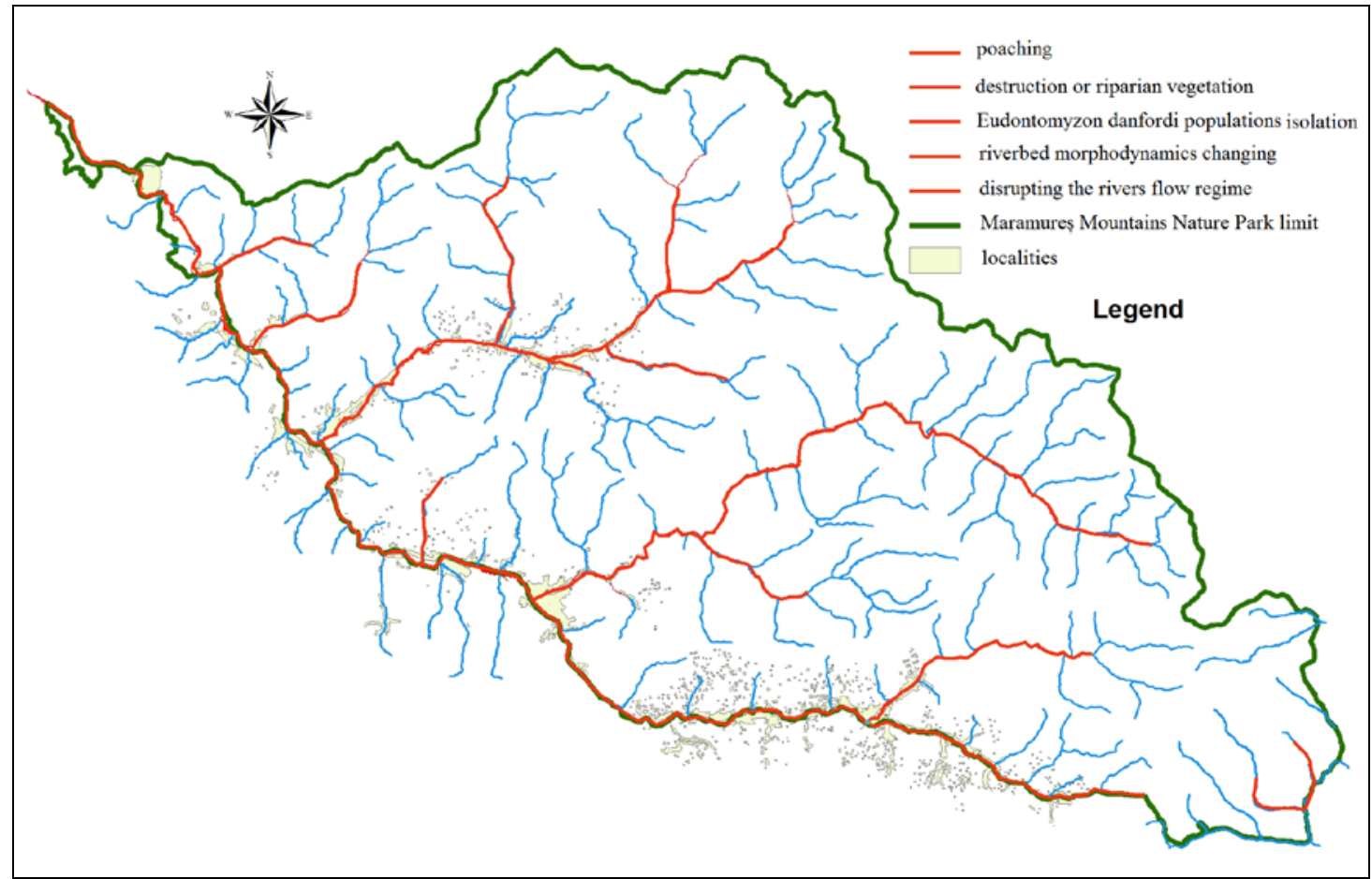

Figure 10: Identified combined pressures and threats for Eudontomyzon danfordi. 
Habitat fragmentation/isolation of population invariably leads to genetic isolation, reduction of gene variability and, sooner or later, species inbreeding and local or regional extinction. The free upstream and downstream displacement, including the various subdrainage basins of the Vișeu catchment area, are a highly important element for their protection and conservation. The relatively low motor skills of the species enhances the importance of this type of man-made impact.

We suggest treating the possible future investments located on the water courses very carefully, since some of them could reduce or completely cut off the longitudinal connectivity on the interest water courses, not only by creating various transversal obstacles in the riverbed, but also by reducing the water flow or even water depriving of some river sectors.

The organic pollution. It is a chronic problem related to the sewage and wastewater treatment as well as to the farms, in the large majority of the Vișeu catchment area, mainly on the Vișeu River, are a permanent stress source for the interest species. Comprehensive sewage systems must be implemented in the Vișeu Basin and the wastewaters of the localities alongside the main water courses must be treated.

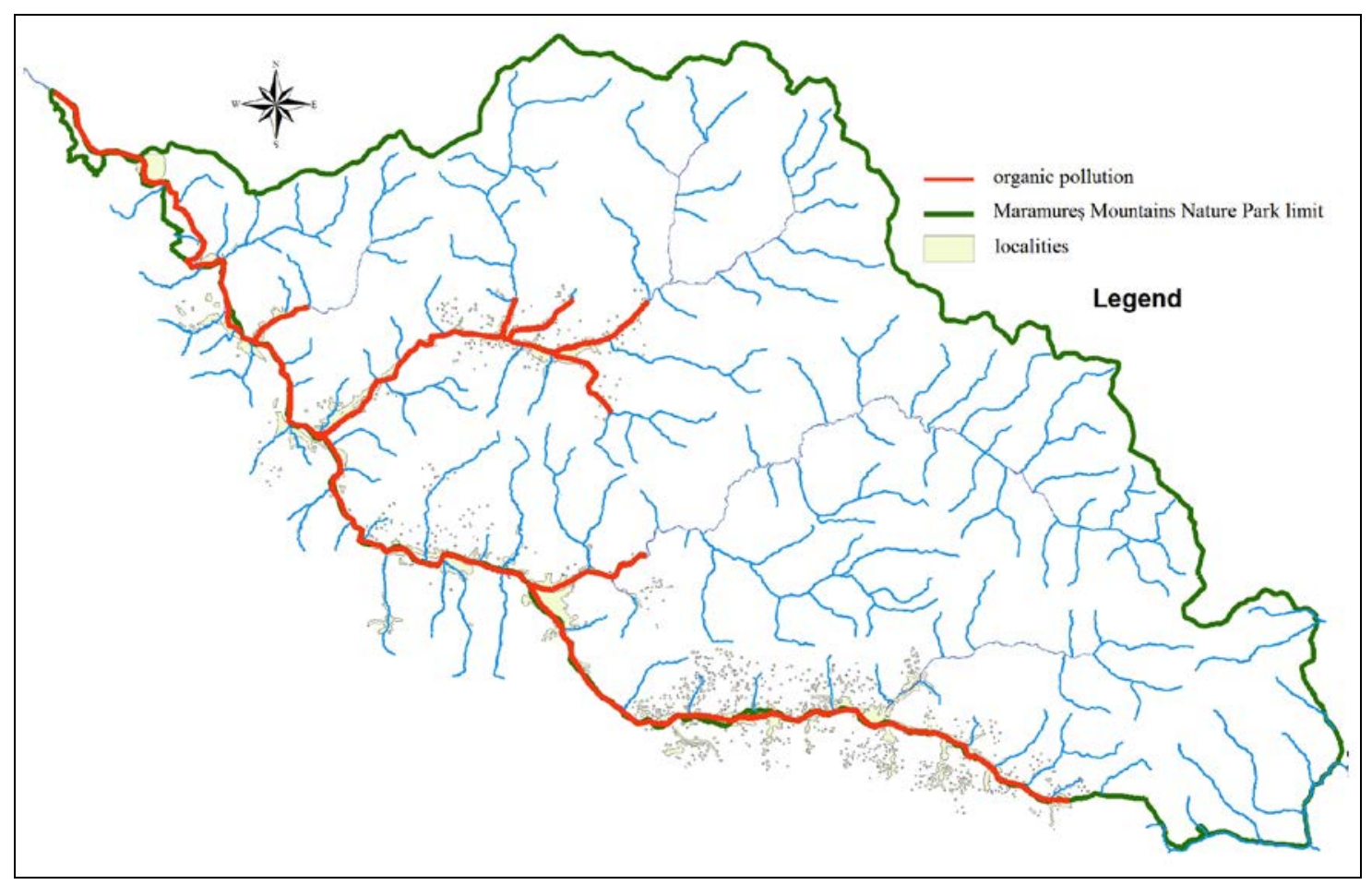

Figure 11: Lotic sectors negatively influenced by organic pollution.

The pollution caused by mining activities. The historical pollution resulting from heavy metal mining activities in the Țâșla drainage basin are not affecting only the Țâş̧la River aquatic habitats but also the interest habitats and species of the upstream Vișeu River. The impact of the meteoric washing waters of the non-isolated mine galleries and greened refuse heaps is ranked as major on the Țâşla River and significant on the upstream Vișeu.

The impacts of meteoric waters washing the non-isolated mine galleries and rehabilitated refuse heaps can be significantly reduced by isolating/filling the ancient mine galleries and by isolating (not greening) the refuse heaps from the water courses in the drainage basin of the Țâșla River. 
Of course the synergism among all the identified human impact effects influence many lotic sectors in the area of interest (Figs. 10 and 11) and evaluating the studied fish species in the area as rare.

The following minimal management measures should be implemented in the studied area: creation of lotic systems buffer zones; coordination of water use; regulation of sewage and waste water and surface water pollution as well; readjust the hydroenergetic use of streams and rivers; implementation of integrated water resource management for the watershed; build and authorize ecological networks; restore streams and rivers connectivity; support high scientific quality inventories and watershed integrated management oriented research.

\section{CONCLUSIONS}

The Eudontomyzon danfordi characteristic habitats state of Maramureş Mountains Nature Park varies greatly among bad, average and good. The identified human impact categories which induce the decreasing habitat state in the studied area are: poaching, minor riverbeds morphodynamic changings, liquid and solid natural flow disruption, destruction of riparian trees and bush vegetation, habitat fragmentation-fish populations isolation, organic pollution and those caused by mining, as a consequence of the identified human impact effects, the Eudontomyzon danfordi species can be considered in the present as a relatively rare species in the studied area.

$19.05 \%$ of the studied lotic sectors (in Vişeu and Vaser rivers) were found in excellent conservation status, $47.62 \%$ of the studied lotic sectors (in Vişeu, Vaser, Ruscova and Frumuşeaua rivers) are in good/average conservation status where medium term restoration is possible with average effort and $33.33 \%$ of the studied lotic sectors (Ruscova and Bistra streams) are in reduced/degraded conditions where long term restoration is difficult. Ruscova and Bistra streams are in the worst situation as from the Eudontomyzon danfordi fish species perspective. 


\section{ACKNOWLEDGEMENTS}

These data were obtained in the project "Inventarierea, cartarea și evaluarea stării de conservare a speciilor de pești din Parcul Natural Munții Maramureșului (ROSCI 0124 Munții Maramureșului)/Inventory, mapping and assessment of the conservation status of fish species of Munții Maramureșului Nature Park (ROSCI 0124 Maramureșului Mountains)". Special thanks for the continuous support of the Parcul Natural Munții Maramureşului Administration and Scientific Council members especially to: Bogdan C., Bucur C., Szabo B., Brener A. and Mărginean M. 


\section{REFERENCES}

1. Bănăduc D., 2007a - Fish of Natura 2000 network interest in Romania, in Romanian NATURA 2000 NGO Coalition contribution for the SCIs designation, Curtean-Bănăduc A. and Florescu F. (eds), Edit. Alma Mater Sibiu, ISBN 978-973-632-402 $-4$.

2. Bănăduc D., 2007b - Specii de pești dulcicoli și migratori în mediul dulcicol, de interes comunitar, prezente în România, în Natura 2000 în România, Conservarea speciilor şi habitatelor acvatice, Curtean-Bănăduc A. (ed.), Alma Mater Sibiu, 72-81. (in Romanian)

3. Bănăduc D., 2008a - Natura 2000 sites proposals regarding the fish species of Community interest in the Romanian Alpine Biogeographical Region, Transylvanian Review of Systematical and Ecological Research, 6, Edit. Universităţii „Lucian Blaga” din Sibiu, 185-196.

4. Bănăduc D., 2008b - Natura 2000 sites proposals regarding the European Community interest fish (Cyclostomata) species (Romania), Acta Oecologica Carpatica, I, 83-88.

5. Bănăduc D., 2011 - New SCIs proposal regarding the ichtiofauna after the Alpine Biogeographic Seminar for Romania, Sibiu (Transylvania, Romania) 9-12 June 2008, Acta Oecologica Carpatica, IV, 199-208.

6. Bănăduc D., Prots B. and Curtean-Bănăduc A. (eds), 2011 - The Upper Tisa River Basin, Transylvanian Review of Systematical and Ecological Research, 11, 204.

7. Bănăduc D., Nagy A. and Bănăduc A., 2012 - New SCIs proposal regarding the ichtiofauna after the Continental Biogeographic Seminar for Romania, Sibiu (Transylvania, Romania) 9-12 June 2008, Acta Oecologica Carpatica, V, 145-158.

8. Bănăduc D., Oprean L., Bogdan A. and Curtean-Bănăduc A., 2012 - The assessment, monitoring and management of the Carpathian rivers fish diversity, Management of Sustainable Development, 4, 1, 19-27.

9. Bănărescu P. M., 1964 - Fauna R. P. Române, Pisces-Osteichthyes, XIII, Edit. Academiei Române, 959. (in Romanian)

10. Bănărescu P. M., 1969 - Fauna R. S. România, Cyclostomata și Chondrichthyes, XII, Edit. Academiei Române, 125. (in Romanian)

11. Bănărescu P. M., 1994 - Der gegenwärtige Stand der Fishfauna Siebenbürgens Naturwissenschaft Forschung Über Siebenbürgen, 5, Böhlau Verl., Köln, Weimar, Wien, 257-258. (in German)

12. Bănărescu P. M. and Bănăduc D., 2007 - Habitats Directive (92/43/EEC) Fish species (Osteichthyes) on the Romanian Territory, Acta Ichtiologica Romanica, II, 43-78.

13. Curtean-Bănăduc A., Bănăduc D. and Sîrbu I. (eds), 2008 - The Maramureş Mountains Nature Park, Transylvanian Review of Systematical and Ecological Research, 5, 222.

14. Curtean-Bănăduc A., Schneider-Binder E. and Bănăduc D., 2014 - The importance of the riverine ligneous vegetation for the Danube Basin lotic ecosystems, in Cianfaglione $\mathrm{K}$. (ed.), L’importanza degli Alberi e del Bosco. Cultura, scienza e coscienza del territorio, Temi Edit., Trento, Italia, ISBN: 978-88-973772-63-9, I-II, 187-210.

15. Homei V., 1963 - Fauna ihtiologică a râului Vişeu şi importanţa ocrotirii ei, Ocrotirea naturii, 7, 129-144. (in Romanian)

16. Staicu G., Bănăduc D. and Găldean N., 1998 - The structure of some benthic macroinvertebrates and fishes communities in the Vișeu Watershed, Maramureș, Romania, Travaux du Museum National d'Histoire naturelle "Grigore Antipa”, București, XL, 587-608. 
17. Telcean I. and Bănărescu P. M., 2002 - Modifications of the fish fauna in the upper Tisa River and its southern and eastern tributaries, Tiscia monograph series, 6, 179-186. 